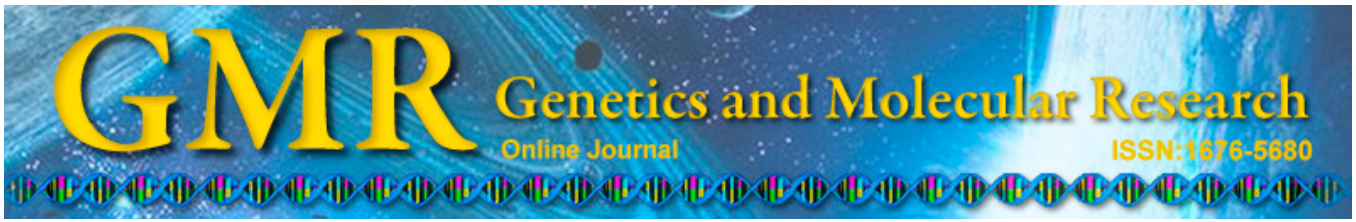

\title{
Genetic variation of Sargassum horneri populations detected by inter-simple sequence repeats
}

\author{
J.R. Ren ${ }^{1,2}$, R. Yang ${ }^{1,2}$, Y.Y. He ${ }^{1,2}$ and Q.H. Sun ${ }^{1,3}$ \\ ${ }^{1}$ School of Marine Science, Ningbo University, \\ Key Laboratory of Applied Marine Biotechnology, Ministry of Education, \\ Ningbo, China \\ ${ }^{2}$ Marine Biotechnology Laboratory, Ningbo University, Ningbo, China \\ ${ }^{3}$ Whenzhou Seatiger Seaweed Cultivation Co., Ltd., Wenzhou, China \\ Corresponding author: R. Yang \\ E-mail: yangrui@nbu.edu.cn
}

Genet. Mol. Res. 14 (1): 619-625 (2015)

Received March 13, 2014

Accepted July 11, 2014

Published January 30, 2015

DOI http://dx.doi.org/10.4238/2015.January.30.3

\begin{abstract}
The seaweed Sargassum horneri is an important brown alga in the marine environment, and it is an important raw material in the alginate industry. Unfortunately, the fixed resource that was originally reported is now reduced or disappeared, and increased floating populations have been reported in recent years. We sampled a floating population and 4 fixed cultivated populations of $S$. horneri along the coast of Zhejiang, China. Inter-simple sequence repeat (ISSR) markers were applied in this research to analyze the genetic variation between floating populations and fixed cultivated populations of $S$. horneri. In total, 220 loci were amplified with 23 ISSR primers. The percentage of polymorphic loci within each population ranged from 53.64 to $95.45 \%$. The highest diversity was observed in population 3 , which was the local species that was suspension cultured in the lab and then fixed cultivated in the Nanji Islands before sampling. The lowest diversity was obtained in the floating population 4 . The genetic distances among
\end{abstract}


the $5 S$. horneri populations ranged from 0.0819 to 0.2889 , and the distance tendency confirmed the genetic diversity. The results suggest that the floating population had the lowest genetic diversity and could not be joined into the cluster branch of the fixed cultivated populations.

Key words: Sargassum horneri; Floating populations; Inter-simple sequence repeat (ISSR); Genetic variation

\section{INTRODUCTION}

Sargassum horneri, a large brown alga, belongs to Phaeophyceae, Fucales, Sargassaceae; it is widely distributed from the mid-littoral to sublittoral zones along the coast of the Pacific Ocean and the adjoining seas of Korea, Japan, and China (Hossain et al., 2003). S. horneri provides the habitat for a number of marine organisms so that they can avoid predators, inhabit, feed, and spawn (Zheng et al., 2008). S. horneri powder is the main feed ingredient of Stichopus japonicus culture, which expanded over 1 million acres in China (Zheng et al., 2008). Chemicals like alginate, laminaran, and fucoidan, which are extensively used in industry, can be extracted from $S$. horneri (Ermakova et al., 2011), and the algal polysaccharides can be used as drugs and drug intermediates because of their anticoagulant activity, antitumor activity, and antiviral activity (Witvrouw and De Clercq, 1997). On the other hand, sodium alginate can be used as an important food additive (O'Sullivan et al., 2010).

Macroalgae farming is an effective means of in situ remediation of the environmental eutrophication, which was an excellent way to protect the environment compared to the use of microalgae and phytoplankton (Yang and Fei, 2003). S. horneri was cultivated in the Nanji Islands, Zhejiang, China, in order to restore the mariculture field, which effectively alleviated the environmental pressure of the islands (Sun et al., 2009).

The natural resources of $S$. horneri were reported to be depleted, leading to sea desertification or "isoyake" areas, because of extensive collection for artificial seaweed breeding, coastal pollution, and herbivore grazing (Fujita, 2010; Nagai et al., 2011). Currently, $S$. horneri is one of the main candidates for seaweed bed reconstruction in Japan, the Republic of Korea, and China (Yamauchi, 1984; Choi et al., 2003; Sun et al., 2009). According to 40 years of observation (1969 to 2009) by Sun et al. (2010), the number of algae species at Mazuao, Nanji Islands, decreased with the gradual change in abundance. The original constructive species became the common species, and some constructive species such as Chondria crassicaulis Harv. and Sargassum fusiforme (Harv.) Setch became uncommon species; furthermore, $S$. horneri disappeared in the intertidal zone during the observation period; thus, the local fixed $S$. horneri cannot be found now. Komatsu et al. (2007) conducted research in the eastern East China Sea during May 2002 and March 2004, which revealed that the floating seaweeds were distributed along the front between the Kuroshio Current and coastal waters and were mainly composed of 1 seaweed species, S. horneri, from spring to early summer. The field survey revealed that Sargassum forests were mainly composed of $S$. horneri around Goqui Island, Shensi Prefecture, Zhejiang Province, China (Komatsu et al., 2007). Additionally, Abé et al. (2013) reported that the floating S. horneri probably originated in the southern East China Sea. In our research, the inter-simple sequence repeat (ISSR) technique was applied to detect the genetic variation of fixed cultivated populations and the floating population of $S$. horneri along the coast of Zhejiang, China. 


\section{MATERIAL AND METHODS}

\section{Sampling}

In total, 5 populations of $S$. horneri were collected from 3 sites from April 2013 to June 2013 along the coast of Zhejiang Province, China (Table 1). The samples were collected randomly and cleaned by distilled seawater to remove the attachments; then, samples were placed in an icebox and taken to the lab as soon as possible. The samples were preserved at $-20^{\circ} \mathrm{C}$ for DNA extraction.

Table 1. Information about 5 Sargassum horneri populations and the sampling location.
\begin{tabular}{llll}
\hline Population & Resource origin & Collection site & Sample time \\
\hline 1 & North cultivar (Dalian) & Nanji Islands; $27^{\circ} 27^{\prime} \mathrm{N}, 121^{\circ} 05^{\prime} \mathrm{E}$ & April 13, 2013 \\
2 & Local cultivar (Nanji) & Nanji Islands; $27^{\circ} 27^{\prime} \mathrm{N}, 121^{\circ} 05^{\prime} \mathrm{E}$ & April 13,2013 \\
3 & Local species suspension cultured in & Nanji Islands; $27^{\circ} 27^{\prime} \mathrm{N}, 121^{\circ} 05^{\prime} \mathrm{E}$ & April 13,2013 \\
& lab and cultivated in the sea (Nanji) & & \\
4 & Floating species (Unknown) & Dongtou; $27^{\circ} 50^{\prime} \mathrm{N}, 121^{\circ} 09^{\prime} \mathrm{E}$ & May 18,2013 \\
5 & Wild species (Dongi) & Dongji Islands; $30^{\circ} 11^{\prime} \mathrm{N}, 122^{\circ} 41^{\prime} \mathrm{E}$ & April 30,2013 \\
\hline
\end{tabular}

\section{DNA extraction}

About 5 leaflets were plucked from the alga plantlet when it was thawed completely, and they were washed thoroughly with disinfected seawater, sterilized in $0.7 \% \mathrm{KI}$ solution for $10 \mathrm{~min}$, and dried on filter paper. After being finely ground with liquid nitrogen, the seaweed powder was transferred to a sterilized $1.5-\mathrm{mL}$ centrifuge tube for DNA extraction. The total genomic DNA was extracted following the cetyltrimethylammonium bromide method (Porebski et al., 1997). The concentrations of the extracted DNA were measured by a NANODROP1000 (Thermo Scientific, USA), and these results correspond with ISSR standards. The DNA quality was tested by $1 \%$ agarose gel electrophoresis.

\section{ISSR amplification}

Twenty-eight ISSR primers were synthesized by Sangon (China), and 23 of these primers were finally selected according to the polymorphism, quality, and stability of the amplification (Table 2). The ISSR reaction system was $20 \mu \mathrm{L}$ and consisted of $15 \mathrm{ng}$ template DNA solution, $10 \mu \mathrm{M}$ primers, $10 \mathrm{X}$ polymerase chain reaction (PCR) buffer, $0.2 \mathrm{mM}$ dNTP mix, $0.2 \mathrm{mM} \mathrm{Mg}^{2+}$, and 1.0 U Taq DNA polymerase (TaKaRa Biotech, China).

Table 2. Inter-simple sequence repeat (ISSR) primers.
\begin{tabular}{lccccc}
\hline Primer & Sequence $\left(5^{\prime}-3^{\prime}\right)$ & Primer & Sequence (5'-3') & Primer & Sequence $\left(5^{\prime}-3^{\prime}\right)$ \\
\hline 807 & $(\mathrm{AG})_{8} \mathrm{~T}$ & 834 & $(\mathrm{AG})_{8} \mathrm{YT}$ & 864 & $\mathrm{~A}(\mathrm{TGA})_{5} \mathrm{TG}$ \\
808 & $(\mathrm{AG})_{8} \mathrm{C}$ & 835 & $(\mathrm{AG})_{8} \mathrm{YC}$ & 866 & $(\mathrm{CTC})_{6}$ \\
809 & $(\mathrm{AG})_{8} \mathrm{G}$ & 841 & $(\mathrm{GA})_{8} \mathrm{YC}$ & 873 & $(\mathrm{GACA})_{4}$ \\
810 & $(\mathrm{GA})_{8} \mathrm{~T}$ & 844 & $(\mathrm{CT})_{8} \mathrm{RC}$ & 880 & GGA(GAG) $)_{2} \mathrm{AGGAG}$ \\
811 & $(\mathrm{GA})_{8} \mathrm{C}$ & 848 & $(\mathrm{CA})_{8} \mathrm{RG}$ & 889 & $\mathrm{BHBG}(\mathrm{AG})_{6} \mathrm{~A}$ \\
812 & $(\mathrm{GA})_{8} \mathrm{~A}$ & 849 & $(\mathrm{GT})_{8} \mathrm{YA}$ & 890 & $(\mathrm{GGAGA})_{3}$ \\
823 & $(\mathrm{TC})_{8} \mathrm{C}$ & $(\mathrm{GT})_{8} \mathrm{YG}$ & 891 & $\mathrm{HVH}(\mathrm{TG})_{7}$ \\
828 & $(\mathrm{TG})_{8} \mathrm{~A}$ & 851 & $(\mathrm{AC})_{8} \mathrm{YT}$ & & \\
\hline$* \mathrm{Y}=\mathrm{C} / \mathrm{T} \cdot \mathrm{R}=\mathrm{A} / \mathrm{G}$ & 855 & & & \\
\hline
\end{tabular}


PCR amplifications were conducted with a thermal cycler (Eppendorf, Germany) with the following conditions: initial denaturation at $94^{\circ} \mathrm{C}$ for $5 \mathrm{~min} ; 40$ cycles of denaturation at $94^{\circ} \mathrm{C}$ for $30 \mathrm{~s}$, annealing at $50^{\circ} \mathrm{C}$ for $45 \mathrm{~s}$, and extension at $72^{\circ} \mathrm{C}$ for $2 \mathrm{~min}$; and a final extension at $72^{\circ} \mathrm{C}$ for $10 \mathrm{~min}$. PCR products were separated on $1.5 \%$ agarose gels in $1 \mathrm{X}$ Tris, acetic acid, ethylenediaminetetraacetic acid buffer. DNA marker DL 2000 (TaKaRa Biotech, China) was used as a size marker. PCR products were recorded with a digital imager (Bio-Rad, USA) after staining with ethidium bromide.

\section{Data analysis}

The ISSR electrophoretic amplification bands were scored for their presence (1) or absence (0), which excluded smeared and weak bands. The results were analyzed by the PopGene 32 software based on the data matrix to obtain the following: 1) the percentage of polymorphic loci (P\%); 2) $N_{\mathrm{A}}$, observed number of alleles; 3) $N_{\mathrm{E}}$, effective number of alleles; 4) $\mathrm{H}$, Nei's (1973) gene diversity; and 5) I, Shannon's information index. The Nei's (1978) unbiased genetic distance (D) between each population was determined, and a dendrogram based on it was constructed by unweighted pair group method with arithmetic mean (UPGMA).

\section{RESULTS}

All of the 220 loci ranged from 100 to $2000 \mathrm{bp}$ in size in the 5 populations, and there was an average of 9.1 loci per primer. The $\mathrm{P} \%$ within each population ranged from 53.64 to 95.45\% (Table 3). The highest parameters were detected in population 3 from Nanji Island $\left(\mathrm{P} \%=95.45 \%, N_{\mathrm{A}}=1.95 \pm 0.21, N_{\mathrm{E}}=1.69 \pm 0.31, \mathrm{H}=0.38 \pm 0.14, \mathrm{I}=0.56 \pm 0.19\right)$, which was the local species that was cultured in the lab. The lowest $\mathrm{P} \%, N_{\mathrm{A}}$, and I were detected in the floating samples of population 4 collected from the Dongtou area ( $\mathrm{P} \%=53.64 \%, N_{\mathrm{A}}=1.54$ $\pm 0.5, \mathrm{I}=0.31 \pm 0.31$ ), while the lowest $N_{\mathrm{E}}$ and $\mathrm{H}$ was observed in the population $2 \mathrm{Nanji}$ local cultivar $\left(N_{\mathrm{E}}=1.31 \pm 0.30, \mathrm{H}=0.20 \pm 0.16\right)$.

Table 3. Genetic diversity of 5 Sargassum horneri populations by ISSR analysis.
\begin{tabular}{lccccccc}
\hline Population & Sample size & $\mathrm{P} \%$ & $N_{\mathrm{A}}$ & $N_{\mathrm{E}}$ & $\mathrm{H}$ & $\mathrm{I}$ \\
\hline 1 & 16 & $76.36 \%$ & $1.76 \pm 0.43$ & $1.41 \pm 0.36$ & $0.24 \pm 0.19$ & $0.37 \pm 0.26$ \\
2 & 17 & $75.45 \%$ & $1.75 \pm 0.43$ & $1.31 \pm 0.30$ & $0.20 \pm 0.16$ & $0.32 \pm 0.23$ \\
3 & 12 & $95.45 \%$ & $1.95 \pm 0.21$ & $1.69 \pm 0.31$ & $0.38 \pm 0.14$ & $0.56 \pm 0.19$ \\
4 & 17 & $53.64 \%$ & $1.54 \pm 0.5$ & $1.38 \pm 0.41$ & $0.21 \pm 0.22$ & $0.31 \pm 0.31$ \\
5 & 20 & $85.45 \%$ & $1.85 \pm 0.35$ & $1.34 \pm 0.29$ & $0.22 \pm 0.16$ & $0.35 \pm 0.22$ \\
Total & 82 & $100.00 \%$ & 2.00 & $1.52 \pm 0.23$ & $0.33 \pm 0.10$ & $0.50 \pm 0.13$ \\
\hline
\end{tabular}

$\mathrm{P} \%=$ percentage of polymorphic loci; $N_{\mathrm{A}}=$ observed number of alleles; $N_{\mathrm{E}}=$ effective number of alleles; $\mathrm{H}=$ Nei's genetic diversity; I = Shannon's information index.

\section{Cluster analysis}

Based on the ISSR markers, the D values among the 5 Sargassum horneri populations ranged from 0.0819 to 0.2889 (Table 4). The lowest value was between populations 2 and 5, and the highest value was between populations 1 and 4 . The genetic identity values ranged from 0.749 to 0.921 . In addition, the lowest value was between populations 1 and 4 , and the 
highest value was between populations 2 and 5. Therefore, the genetic identity and genetic distance exhibited the same tendency.

The UPGMA dendrograms (Figure 1) based on ISSR data showed that populations 2 and 5 clustered together first, then with populations 1 and 3, and finally with population 4 .

Table 4. Nei's unbiased measures of genetic identity and genetic distance.
\begin{tabular}{lccccc}
\hline Population & 1 & 2 & 3 & 4 & 5 \\
\hline 1 & - & 0.8860 & 0.8072 & 0.7491 & 0.9037 \\
2 & 0.1211 & - & 0.8065 & 0.7671 & 0.9213 \\
3 & 0.2141 & 0.2151 & 0.2466 & 0.7814 & 0.8314 \\
4 & 0.2889 & 0.2652 & - & 0.2840 & 0.7528 \\
5 & 0.1013 & 0.0819 & 0.1847 & \\
\hline
\end{tabular}

Nei's genetic identity (above diagonal) and genetic distance (below diagonal).

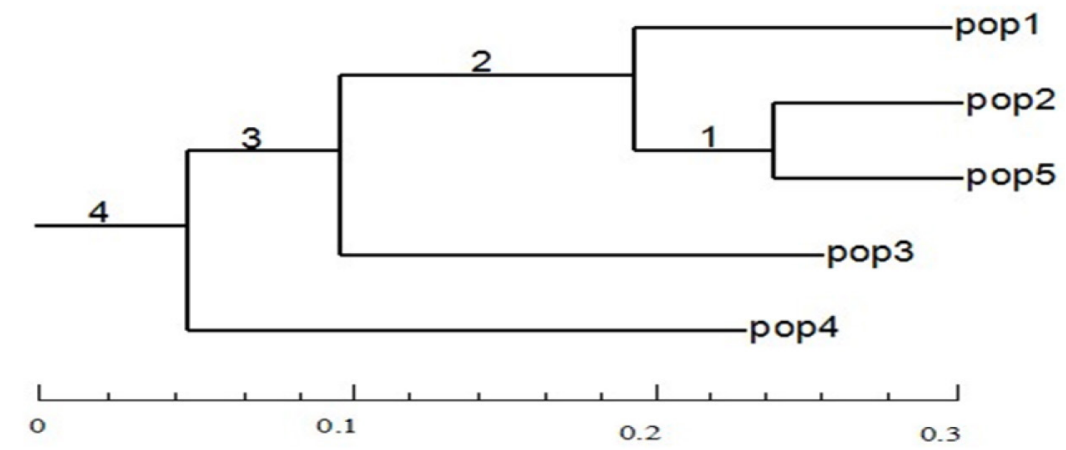

Figure 1. Unweighted pair-group method with arithmetic mean dendrogram of the Sargassum horneri populations.

\section{DISCUSSION}

Generally, natural selection factors, geographical distance, and ecological factors, such as current systems, temperature, and salinity, in specific geographical locations influence the genetic diversity of Sargassum (Sun and Lin, 2003). Zhao et al. $(2007,2008)$ reported that a comparatively low genetic variation, a $\mathrm{P} \%$ of about $40-50 \%$, among Sargassum thunbergii populations and Sargassum muticum populations was revealed by ISSR and random amplification of polymorphic DNA (RAPD). Similar results were obtained in studies on Sargassum species in Oman Sea by Noormohammadi et al. (2011). Yu et al. (2013) reported that high genetic variability and differentiation existed among $S$. horneri populations: the inter-population P\% was 99.4 and $100.0 \%$ by ISSR and RAPD, respectively. In the same study, the highest P\% within a population was detected in the YT and NJ populations (50\%). Our results showed a higher intra-population $\mathrm{P} \%$ of $95.45 \%$ in population 3 than in Yu et al.'s study. Population 3 was the collection of fixed wild seaweeds from Nanji Islands; this population was once a suspension culture in the lab for several months and then was cultivated along the Nanji coast before sampling. The north cultivar of population 1 that originated from Dalian (north of the Yellow Sea), the local cultivar of population 2 from Nanji, and the wild samples of population 5 from the Zhoushan Islands shared a similar genetic diversity, which indicated that the diversity 
of these populations had little relation to the origin areas. The floating population 4 showed the lowest diversity, which coincided with the result that the genetic diversity of floating populations is lower than that of fixed populations (Zhao, 2012). Theoretically, populations 2 and 3 originated from the same area; therefore, they should have similar genetic variation, but our results did not support this assumption.

Yu et al. (2013) reported that the genetic differentiation of the S. horneri populations along China's coast agreed with the geographic isolation, but some populations are genetically closer than others, even when these populations are widely separated geographically. The cluster results of our study also showed the closed genetic distance between populations 1,2, and 5 , which originated broadly from the north to south. Meanwhile, populations 1 and 3, which had the same origin, were not joined in 1 branch, which differed from the results of Zhao et al. (2008). The only difference between these populations was that population 3 was once suspension cultured in the lab. Whether this behavior changes the genetic structure of the seaweed is not clear. An interesting observation was that the floating population 4 was separated from the other populations. The genetic distance relationship and the cluster dendrogram showed that population 4 was different from the other populations. These results did not support the hypothesis that the floating $S$. horneri possibly originated in the southern part of the East China Sea (Pang et al., 2009; Abé et al., 2013).

\section{ACKNOWLEDGMENTS}

Research supported by the China Spark Program (\#2013GA701001), the Natural Science Foundation of Zhejiang (\#LY12D06003), the National Scientific and Technological Support Plan Subject (\#2011BAD13B08), and the Ningbo Marine Algae Biotechnology Team (\#2011B81007).

\section{REFERENCES}

Abé H, Komatsu T, Kokubu Y, Natheer A, et al. (2013). Invertebrate fauna associated with floating Sargassum horneri (Fucales: Sargassaceae) in the East China Sea. Species Divers. 18: 75-85.

Choi CG, Kim HG and Sohn CH (2003). Transplantation of young fronds of Sargassum horneri for construction of seaweed beds. J. Korean Fish. Soc. 36: 469-473.

Ermakova S, Sokolova R, Kim SM, Um BH, et al. (2011). Fucoidans from brown seaweeds Sargassum horneri, eclonia cava, costaria costata: structural characteristics and anticancer activity. Appl. Biochem. Biotechnol. 164: 841-850.

Fujita D (2010). Current status and problems of isoyake in Japan. Bull. Fish. Res. Agen. 32: 33-42.

Hossain Z, Kurihara H and Takahashi K (2003). Biochemical composition and lipid compositional properties of the brown alga Sargassum horneri. Pak. J. Biol. Sci. 6: 1497-1500.

Komatsu T, Tatsukawa K, Filippi JB, Sagawa T, et al. (2007). Distribution of drifting seaweeds in eastern East China Sea. J. Marine Syst. 67: 245-252.

Nagai S, Yoshida G and Tarutani K (2011). Change in Species Composition and Distribution of Algae in the Coastal Waters of Western Japan. In: Global Warming Impacts - Case Studies on the Economy, Human Health, and on Urban and Natural Environments (Casalegno S, ed.). Intech, 209-236.

Nei M (1973). Analysis of gene diversity in subdivided populations. Proc. Natl. Acad. Sci. U. S. A. 70: 3321-3323.

Nei M (1978). Estimation of average heterozygosity and genetic distance from a small number of individuals. Genetics 89: 583-590.

Noormohammadi Z, Ghasemzadeh Baraki S and Sheidai M (2011). Preliminarily report on molecular diversity of Sargassum species in Oman Sea by using ISSR and RAPD markers. Acta Biol. Szegediensis 55: 19-26.

O’Sullivan L, Murphy B, Mcloughlin P, et al. (2010). Prebiotics from marine macroalgae for human and animal health applications. J. Marine Drugs 8: 2038-2064.

Pang SJ, Liu F, Shan TF, Gao SQ, et al. (2009). Cultivation of the brown alga Sargassum horneri: sexual reproduction 
and seedling production in tank culture under reduced solar irradiance in ambient temperature. J. Appl. Phycol. 21: 413-422.

Porebski S, Bailey LG and Baum BR (1997). Modification of a CTAB DNA extraction protocol for plants containing high polysaccharide and polyphenol components. Plant Mol. Biol. Rep. 15: 8-15.

Sun Y and Lin FC (2003). Analysis of genetic diversity in natural germplasm of Lentinula edodes in China using RAPD technique. Mycosystema 22: 387-393.

Sun JZ, Zhuang DG, Wang TG, Zheng JB, et al. (2009). Design and primary enforcement of Sargassum horneri ground establishment around Nanji Islands. Modern Fish. Inform. 24: 25-28.

Sun JZ, Ning XR, Le FF, Chen WD, et al. (2010). Long term changes of biodiversity of benthic macroalgae in the intertidal zone of the Nanji Islands. Acta Ecol. Sin. 30: 106-112.

Witvrouw M and De ClercqE (1997). Sulfated polysaccharides extracted from sea algae as potential antiviral drugs. Gen. Pharmacol. 29: 497-511.

Yamauchi K (1984). The formation of Sargassum beds on artificial substrata by transplanting seedlings of S. horneri (Turner) C. Agardh and S. muticum (Yendo) Fensholt. Bull. Jpn. Soc. Sci. Fish. 50: 1115-1123.

Yang YF and Fei XG (2003). Prospects for bioremediation of cultivation of large-sized seaweed in eutrophic mariculture areas. J. Ocean Univ. Qingdao 33: 53-57.

Yu SH, Chong Z, Zhao FJ, Yao JT, et al. (2013). Population genetics of Sargassum horneri (Fucales, Phaeophyta) in China revealed by ISSR and SRAP markers. Chin. J. Oceanol. Limnol. 31: 609-616.

Zhao J (2012). Genetic analysis of Ulva prolifera-the causative species of the Yellow Sea Green Tides. Doctoral thesis. Institute of Oceanology, Qin Dao.

Zhao FJ, Wang XL, Liu JD and Duan DL (2007). Population genetic structure of Sargassum thunbergii (Fucales, Phaeophyta) detected by RAPD and ISSR markers. J. Appl. Phycol. 19: 409-416.

Zhao FJ, Liu FL, Liu JD, Ang PO Jr, et al. (2008). Genetic structure analysis of natural Sargassum muticum (Fucales, Phaeophyta) populations using RAPD and ISSR markers. J. Appl. Phycol. 20: 191-198.

Zheng HY, Rao DZ, Chen GF and Sun JZ (2008). Consideration on protective exploitation of Sargassum horneri (Turn.): a resource around Nanji Islands. Modern Fisheries Information. 23: 25-26. 